\title{
GRZEGORZ OJCEWICZ
}

Uniwersytet Warmińsko-Mazurski w Olsztynie

iD ORCID https://orcid.org/0000-0002-5909-270X

\section{WIECZÓR... W 2217 ROKU NIKOŁAJA FIODOROWA JAKO PROTEST-ANTYUTOPIA}

\author{
NIKOLAI FYODOROV'S STORY ONE EVENING... IN 2217 \\ AN ANTI-UTOPIAN PROTEST
}

One evening... in 2217, a short story by Nikolai Fyodorov, was published in 1906. In the history of the Russian literature, this story has the status of a pioneering anti-utopian text. From this point of view, it is interesting to examine the text as a literary experiment in which the author presents to his readers his vision of a new world seen from the distance of three-hundred-years. What does the author find especially worrying about a future world in which the values of the present no longer exist? Who is the author rebelling against and why? Why does his text reference Anna Karenina by Leo Tolstoy? What made his story a source of inspiration for Yevgeny Zamyatin's We? Why does Fyodorov continue to inspire Russian anti-utopian writers of the 20th and 21st century who use this genre to voice their opinions on topical and socially significant issues?

Keywords: Nikolai Fyodorov, protest, anti-utopia, a family of the future

ВЕЧЕР... В 2217 ГОДУ НИКОЛАЯ ФЕДОРОВА КАК ПРОТЕСТ-АНТИУТОПИЯ

Рассказ Николая Федорова Вечер... в 2217 году был опубликован в 1906 году. В истории русской литературы он считается новаторским текстом, в котором реализуется антиутопия. С этой точки зрения интересным кажется 
исследование данного произведения с позиции литературного эксперимента, в котором автор приближает читателю новый мир с очень отдаленной, ибо свыше 300-летней, перспективы. Что особенно беспокоит писателя, раз проектирует он будущее, в котором, по его мнению, мы уже не найдем современных ему ценностей? Кому и чему сопротивляется автор? Почему его текст обращается к Анне Карениной Льва Толстого и служит вдохновением для $\mathrm{Mbl}$ Евгения Замятина? Почему Федоров постоянно вдохновляет русских антиутопистов XX и XXI столетий для высказывания мнений по поводу насущных общественных проблем?

Ключевые слова: Николай Федоров, протест, антиутопия, семья будущего

Pierwsza rzecz, na którą zwróciłem uwagę przed lekturą tego opowiadania, wiąże się z datowaniem analizowanego utworu: 1906 rok. Uprzedzając nieco dalszą narrację, powiem tylko, że fakt ten miał znaczenie kluczowe w identyfikacji autorstwa tekstu i jego interpretacji. To ważne, ponieważ wskazanie prawdziwego, a nie rzekomego twórcy Wieczoru... połączone z wprowadzeniem jego nazwiska do polskiej rusycystyki chroni rodzimego odbiorcę przed ewentualnym trwaniem w błędzie solidnie już utrwalonym w mediach rosyjskich ${ }^{1}$. Na czym polega ten błąd? Na przypisywaniu danego opowiadania wielkiemu myślicielowi rosyjskiemu Nikołajowi Fiodorowiczowi Fiodorowowi, który w rzeczy samej nie ma nic wspólnego z tym tekstem, chociaż wydawać by się mogło, że mógłby mieć, jeśli uwzględni się ogromną różnorodność tematyczną (np. filozofia, religia, estetyka, przyrodoznawstwo, literatura, sztuka, bibliotekoznawstwo) oraz gatunkową Fiodorowa na niwie pisarskiej. Rzeczywistość koryguje jednak ostatecznie to początkowe mylne przeświadczenie.

W 1906 roku Nikołaj Fiodorow (1829-1903) już nie żył, więc nawet gdyby był autorem Wieczoru..., nie zdołałby wskazać na 1906 rok jako moment powstania „własnego” tekstu. Musiałoby zatem to datowanie roczne pochodzić na przykład od pierwszego edytora, lecz na ten temat dostępne źródła milczą, chociaż Wieczór

\footnotetext{
${ }^{1}$ Zob. przykładowe adresy stron internetowych, gdzie podaje się błędnie, że Nikołaj Fiodorowicz Fiodorow jest autorem opowiadania Wieczór w 2217 roku: https://bookshake.net/b/vecher-v-2217-godu-nikolay-fedorovich-fedorov, https://royallib.com/author/fedorov_nikolay.html, https://bookscafe.net/ author/fedorov_nikolay-7061.html, https://avidreaders.ru/book/vecher-v-2217-godu.html (6.01.2021).
} 
w 2217 roku - pod takim właśnie, pozbawionym wielokropka tytułem - systematycznie wchodził do dawnych i wciąż wchodzi do najnowszych antologii rosyjskich (wcześniej — radzieckich) oraz publikowanych poza granicami Rosji (ZSRR). Fakt ten najlepiej świadczy o szczególnych walorach literackich dystopii², a także o jej gatunkowej aktywności w różnych okresach historycznych w tym państwie ${ }^{3}$. Wiadomo, że rosyjski filozof, który wszelką własność nawet w sferze idei czy twórczości artystycznej - utożsamiał z grzechem, sam za życia świadomie nie publikował swoich prac i dlatego pierwsza ich postać drukowana, właśnie z 1906 roku, została przygotowana przez uczniów Fiodorowa ${ }^{4}$. Rok ten inicjował zatem częściowe udostępnienie dorobku filozofa jako myśliciela, ale nie jako pisarza, autora Wieczoru...

Drugie moje zdziwienie - przekute następnie w argument wyniknęło z faktu, że najobszerniejsze jak dotąd wydanie dzieł wszystkich autora Filozofii wspólnego czynu nie zawiera żadnego tekstu literackiego, co zasadnie sugeruje, że albo analizowane opowiadanie nie należy do Nikołaja Fiodorowicza Fiodorowa i dlatego

${ }^{2}$ Terminem „dystopia” posługuję się tutaj synonimicznie $\mathrm{z}$ terminem „antyutopia”, chociaż mam świadomość, że zdania badaczy są pod tym względem podzielone: część z nich traktuje dystopię i antyutopię jako semantyczne ekwiwalenty, inni natomiast wskazują na cechy dystopii, które nie pozwalają na ich zamienne stosowanie. Autorzy dystopii, w odróżnieniu od twórców antyutopii, kreślą pesymistyczne wizje przyszłości, odwołując się bezpośrednio do rzeczywistości. Z kolei antyutopiści szukają nierzadko pomysłów na radykalną zmianę ludzkiej egzystencji w utopijnych programach naprawy świata.

${ }^{3}$ Zob. np. В. Шестаков (red.), Русская титературная утопия, Издательство Московского университета, Москва 1986; В. Шестаков (oprac.), Вечер в 2217 году, Прогресс, Москва 1990; Ю. Медведев (орrac.), Русская фантастика конца ХІХ - начала ХХ века, t. 10: Вечер в 2217 году, Русская книга, Москва 1998; А. Гулый, В. Исаев (oprac.), Полдень, ХІХ век, Корпорация „Сомбра”, Москва 2005; Y. Howell (red.), Red Star Tales: A Century of Russian and Soviet Science Fiction, Russian Life Books, Montpelier (VT) 2015; J. Womack (red.), Ciencia ficción rusa y soviética, t. 1, Ediciones Nevsky, Madrid 2016. Opowiadanie Nikołaja Fiodorowa zostało także wydrukowane w czasopiśmie „DARKER” 2016, nr 12’16 (69).

${ }^{4}$ Zob. Н.Ф. Федоров, Философия общего дела, t. 1, Тип. Семиречен. Областного правления, Верный 1906; t. 2, Печатня А. Снегиревой, Москва 1913. 
nie mogło być uwzględnione przez redaktorów opracowania ${ }^{5}$, albo jest on jego autorem, lecz na skutek arbitralnej decyzji edytorskiej nie weszło ono do opera omnia. Nie sądzę jednak, aby w sytuacji, gdyby Fiodorow rzeczywiście był autorem Wieczoru..., tak odpowiedzialni redaktorzy czterotomowej edycji jego prac pominęli tę literacką wypowiedź ${ }^{6}$. Nawet jako tekst kuriozalny pasowałby on całkowicie do innych kontrowersyjnych idei twórcy rosyjskiego kosmizmu i stanowił oryginalny głos w sprawach dotyczących przyszłości ludzkości.

Trzecie natomiast zaskoczenie wzięło się z faktu, że autorstwo Wieczoru... rosyjski internet wiąże z jeszcze innym Nikołajem Fiodorowem, tym razem o patronimiku Timonowicz. Owszem, istnieje taki pisarz, twórca m.in. popularnych utworów dla dzieci, lecz urodził się on w 1946 roku, co z definicji przekreśla jego autentyczność jako nadawcy analizowanego tekstu, opublikowanego w 1906 roku, a więc sporo przed narodzinami przyszłego twórcy ${ }^{7}$. Dlatego dowód najistotniejszy, bo podany przez petersburską badaczkę

${ }^{5}$ Н.Ф. Федоров, Собрание сочинений: в 4-х mm., орrac. И.И. Блауберг, Прогресс-Традиция, Evidentis, Москва 1995-2004.

${ }^{6} \mathrm{O}$ Nikołaju Fiodorowiczu Fiodorowie jako twórcy Wieczoru... nie wspomina się w żadnym z polskich opracowań naukowych, co stanowi kolejny dowód pośredni w sprawie autorstwa tego opowiadania. Ograniczam się z konieczności do przedstawienia w układzie chronologicznym reprezentatywnych egzemplifikacji: R. Łużny, Myśl filozoficzna Mikołaja Fiodorowa w kregu pisarzy rosyjskich XIX i XX wieku, „Przegląd Humanistyczny” 1982, nr 1-2, s. 99-116; K. Pietrzycka-Bohosiewicz, „Przerzucić most nad rzeka czasu...” Nikołaj Fiodorow i pisarze rosyjscy, w: H. Waszkielewicz i J. Świeży (red.), Cmроитель чудотворньй. Szkice o literaturze rosyjskiej dedykowane Jadwidze Szymak-Reiferowej i Władysławowi Piotrowskiemu, Tertium, Kraków 2001, s. 105-111; M. Madej-Cetnarowska, Myśl Nikołaja Fiodorowa w literaturze dziewiętnastego i dwudziestego wieku, Wydawnictwo Naukowe Państwowej Wyższej Szkoły Zawodowej w Nowym Sączu, Nowy Sącz 2013.

${ }^{7}$ Zob. przykładowe adresy stron internetowych, na których Nikołaj Timonowicz Fiodorow uchodzi za autora opowiadania Wieczór w 2217 roku: https://readli. net/avtor/fedorov-nikolay-timonovich-2/, https://lib.alkar.net.ua/books/90949. html, https://lib.alkar.net.ua/authors/28877.html, https://www.rulit.me/authors/fedorov-nikolaj, https://www.litmir.me/a/?id=81724 (6.01.2021).

RSL.2021.31.06 s. 4 z 19 
Lubow Bugajewą, odnajduję w jej artykule z 2012 roku $^{8}$. Autorka wskazała w nim wprost na stołecznego dziennikarza (!) Nikołaja D.[mitrijewicza?] Fiodorowa jako nadawcę opowiadania Wieczór... w 2217 roku. Bugajewa odwołała się przy tym do pierwszej, a więc bardzo ważnej - z punktu widzenia identyfikacji autora - publikacji z 1906 roku zawierającej interesujący nas tekst ${ }^{9}$. Co istotne i do czego należy moim zdaniem powrócić, pierwotnie w tytule opowiadania Fiodorowa występował wielokropek jako sygnał zapowiedzi czegoś niezwykłego: Wieczór.. w 2217 roku. Przyznać trzeba, że śmiałe spojrzenie petersburskiego żurnalisty w przyszłość, narracyjny skok z roku 1906 do 2217, oznaczał nakreślenie perspektywy obejmującej 311 lat, a więc zbyt pojemnej i odległej, by na początku XX wieku można było ją w sposób naukowy w pełni zweryfikować. Nic nie jest wszakże jeszcze przesądzone, gdy chodzi o trafność wizji Fiodorowa, ponieważ w roku 2021 mija 196 lat od wydania drukiem analizowanego opowiadania, a do docelowego roku 2217 pozostało 115 lat; wszystko zatem może się jeszcze wydarzyć, zwłaszcza że żyjemy w czasach, w których wszystkie dziedziny życia rozwijają się bardzo dynamicznie. Na pewno zaś ludzkość minęła już połowę tej futurystycznej ścieżki, co pozwala dzisiaj spojrzeć na narracyjną propozycję petersburskiego pisarza także z punktu widzenia najlepszych zdobyczy w obszarze dawnej i najnowszej antyutopijnej literatury rosyjskiej.

O samym Nikołaju D. Fiodorowie wiemy doprawdy niewiele. Nawet lata jego życia wciąż są owiane tajemnicą. Można jedynie przypuszczać na podstawie zdarzeń pośrednich, że urodził się on około 1870 roku, skoro z jego nazwiskiem kojarzy się inny tekst antyutopijny pod tytułem Atawizm (Aтавизм, 1899), wydrukowany w czasopiśmie „Moskowskije wiedomosti” („Московские ведомости”) i podpisany enigmatycznie „Н. Ф.-Д.-Р. - В.- Ђ” ${ }^{10}$.

8 Л.Д. Бугаева, Топос и телос петербургской утопии: Николай Федоров, „Международный журнал исследований культуры” 2012, nr 4 (9), s. 71-75.

${ }^{9}$ Н. Федоров, Вечер... в 2217 году с послесловием, Типо-Литогр.[афия] „Герольд", С.[анкт]-Петербург 1906.

${ }^{10}$ Н. Федоров, Вечер в 2217 году, w: Фантастика Серебряного века, t. 7: Бомба профессора Штурмвельта, орrac. М. Фоменко, А. Шерман, Salaman- 
Zakładam bowiem, że w wieku prawie 30 lat petersburski dziennikarz mógł już być w pełni artystycznie uformowanym człowiekiem. Hipotetycznie mógłby żyć nawet 120 lat ${ }^{11}$, a więc rok 1990 byłby wtedy datą graniczną jego ziemskiej egzystencji. Zapewne cezura ta jest nadto optymistyczna, gdy uwzględni się czasy rewolucji październikowej, wojny domowej, wielkiej wojny ojczyźnianej i epoki stalinowskiej. W każdej z tych dziejowych zawieruch sowieckich Fiodorow mógł przedwcześnie zginąć z rąk bolszewików albo stracić życie podczas blokady Leningradu. Wiedzę na temat Atawizmu zawdzięczamy streszczeniu, które znalazło się w książce Leonida Hellera i Michela Niqueux Histoire de l'utopie en Russie (cytuję za wydaniem rosyjskim):

Герой рассказа Федорова Атавизм засыпает, чтобы через 500 лет проснуться на острове, занятом „Общиной разумных”. Обитатели, одетые в одинаковые одежды и лишенные пола (хирургическим путем), чтобы полностью отдавать себя труду, носят номера из букв и цифр, позволяющие определить их местоположение на острове, размеченном административно сеткой. Посреди острова находится небоскреб директора Комитета, украшенный гигантской статуей муравья. Жители острова устраняются с помощью эвтаназии после того, как становятся бесполезными для общества (к 45 годам). Язык общения сведен к телеграфному стилю. Пары мужчин и женщин, „живущих по-старому”, обеспечивают репродукцию населения на „фермах”, дети отбираются у них и воспитываются обществом. „Атавические” чувства (любовь, сострадание) - величайшие враги этого общества, отрицающего личность. В конце повести один „больной”, почувствовавший жалость к двум детям, угоняет межпланетный корабль ${ }^{12}$.

Atawizm jest zatem ogniwem poprzedzającym najprawdopodobniej bezpośrednio Wieczór... w 2217 roku. Wiele na to wskazuje,

dra P.V.V., Москва 2018, s. 39-56, http://az.lib.ru/f/fedorow_n_d/text_1906_ vecher.shtml (6.01.2021).

${ }^{11}$ Zgodnie z wolą Stwórcy wyrażoną w Księdze Rodzaju (Rdz 6,3) „Człowiek jest istotą cielesną i jego życie ma trwać nie dłużej niż sto dwadzieścia lat”. Księga Rodzaju, przeł. i oprac. M. Piela, Wydawnictwo Księgarnia Akademicka, Kraków 2020, s. 33.

312 Л. Геллер, М. Нике, Утопия в России, przeł. z franc. И.В. Булатовский, Гиперион, Санкт-Петербург 2003, e-book, s. 181-182. 
najbardziej temat przewodni, którym jest problem kontrolowanej prokreacji i unifikacja osobowości. Wyliczę więc te najważniejsze cechy strukturalne utworu Fiodorowa z 1899 roku, by łatwiej było uchwycić jego odrębność oraz bliskość tej dystopii w zestawieniu z kolejną jej egzemplifikacją z 1906 roku. Głównym bohaterem Atawizmu jest mężczyzna, Wieczoru... - kobieta. Taki zabieg kompozycyjny umożliwił autorowi literacką ocenę tych samych lub podobnych problemów z perspektywy różnych płci: punktu widzenia mężczyzny i kobiety. Mówienie przez protagonistów o sprawach dla nich najważniejszych unisono świadczy nie tylko o konsekwencji narracyjnej Fiodorowa, lecz także uwypukla ponownie podjętą przez pisarza problematykę.

W Atawizmie rzecz cała dzieje się w odmiennym stanie świadomości, albowiem bohater najpierw zasypia, by następnie po 500 latach obudzić się na bezimiennej (a więc dowolnej) wyspie zamieszkiwanej przez „Wspólnotę rozumnych”. W Wieczorze... akcja toczy się w Petersburgu, a więc w konkretnym z nazwy i położenia geograficznego mieście, jeszcze dziwniejszym niż w książkach Nikołaja Gogola, wzdłuż i w okolicach Newskiego Prospektu oraz Prospektu Litiejnego. W ten sposób Fiodorow sugeruje, być może, kierunek futurystycznej transpozycji przestrzennej człowieka: od określonego punktu na mapie do nie wiadomo dokąd. W utworze z 1899 roku mieszkańcy wyspy są odziani jednakowo (uniformizacja doskonale znana z czasów komunistycznych systemów totalitarnych) i na skutek ingerencji chirurgicznej zostali pozbawieni cech płciowych (uniseksizm). Takiej skrajnej unifikacji cielesności nie ma w Wieczorze..., ale pamiętajmy, że i perspektywy czasowe w obydwu tekstach są inne: $\mathrm{z}$ jednej strony znaczniejsza, bo 500-letnia i lokująca się w przestrzeni 2399 roku, a druga - krótsza, bo 311-letnia, przenosząca czytelnika do 2217 roku.

Celem fizycznego okaleczania istot ze „Wspólnoty rozumnych”, bo tak naprawdę do końca nie wiemy, ile jeszcze pozostało w nich pierwiastka czysto ludzkiego, jest odgórne, pozbawione pytania o zgodę, podporządkowanie się mieszkańców wyspy określonej ideologii rządzących, która nakazuje obywatelom w pełni poświęcić się pracy, co sugeruje, że od pracy zależy na tej wyspie wszystko, 
a może i to, że gdy istota ciężko pracuje fizycznie, nie ma czasu na rozmyślania. Jakże charakterystyczne są to i niezwykle czytelne reguły estetyczne narzucone w 1934 roku przez Związek Pisarzy Radzieckich światu kultury sowieckiej i konsekwentnie egzekwowane w kolejnych dziesięcioleciach przez kremlowski aparat władzy. Ani o założeniach ideologicznych stalinowskiej polityki kulturalnej, ani o socrealizmie jako jedynej estetyce komunistycznego państwa nie mógł nic wiedzieć Fiodorow zarówno w 1899, jak i w 1906 roku.

„Wspólnotę rozumnych”, a więc określony rodzaj komuny, lecz paradoksalnie w ogóle nie-demokratycznej, zamieszkują w administracyjnych kwartałach żywe numery, będące konfiguracją liter i cyfr. Ta stygmatyzacja ma zapewnić organom kontrolnym szybkie namierzenie każdego obywatela w razie potrzeby. Ten sam „numeryczny system kadrowy” funkcjonuje także w Wieczorze..., chociaż narrator ujawnia imiona swoich bohaterów, a został on perfekcyjnie zobrazowany w jednej z najgłośniejszych antyutopii rosyjskich pierwszej połowy XX wieku $M y(M b l, 1924)$ Jewgienija Zamiatina. Pośrodku wyspy znajduje się drapacz chmur, który zajmuje dyrektor Komitetu. Budynek upiększa gigantyczny posąg mrówki niczym Statua Wolności na Liberty Island u ujścia rzeki Hudson. Aluzja do amerykańskiego symbolu swobody jest, jak sądzę, bardzo czytelna. Petersburg w Wieczorze... też nie przypomina zwykłego rozwiązania architektonicznego, ponieważ nad miastem rozpościera się kopuła prewencyjna, której zadaniem jest ochrona metropolii przed utratą ciepła, co umożliwia m.in. hodowanie egzotycznych roślin o każdej porze roku. Petersburska kopuła kojarzy się natychmiast z każdym murem (zielonym, białym, czerwonym i każdego innego koloru) znanym z rosyjskich współczesnych antyutopii: od $M y$ Zamiatina do dystopijnej powieści Dzień oprycznika (День опричника, 2006) Władimira Sorokina, gdzie każda sztuczna granica stanowi barierę, której w totalitarnym państwie pod żadnym pozorem nie należy samowolnie przekraczać.

W Atawizmie likwidacja istot następuje poprzez eutanazję w momencie, gdy władza wskazuje na ich nieprzydatność dla społeczeństwa, co ma miejsce najczęściej przed ukończeniem przez obywatela 45. roku życia. W Wieczorze... ta kwestia nie występuje, lecz 
wciąż funkcjonuje instytucja samobójstwa jako sposobu rozwiązania problemów osobistych. Śmierć na własne życzenie nie wywołuje szczególnych emocji u tych, którzy się o niej dowiadują, o czym najlepiej świadczy reakcja Pawła, gdy ze skaczących czerwonych liter elektronicznego biuletynu na ulicy Morskiej dowiaduje się, że „На воздушной станции № 3, гражданка № 4372221 бросилась под воздушник ${ }^{13}$ и поднята без признаков жизни. Причины неизвестны" 14 .

W utworze z 1899 roku mieszkańcy wyspy posługują się językiem mocno sformalizowanym, przypominającym najbardziej suchy styl telegramu. Z kolei w antyutopii Fiodorowa z 1906 roku ludzie wciąż ze sobą rozmawiają, jak w dawnych czasach, ale w języku wielu występują sztampy leksykalne, a „interpretacja” rzeczywistości jest całkowicie zgodna z tym, co zaprogramowali „inżynierowie dusz”. $\mathrm{W}$ Atawizmie znajdujemy więcej w porównaniu z Wieczorem... szczegółów na temat reprodukcji: do współżycia pomiędzy kobietami i mężczyznami dochodzi na fermach (!). Żyją oni „po staremu”, płodzą dzieci, które są im odbierane i oddawane na wychowanie społeczeństwu. Ta sama idea „prosocjalnej prokreacji” występuje w tekście Fiodorowa z 1906 roku, co raz jeszcze wskazuje na jej istotność dla samego autora, który po siedmiu latach nadał jej nowy literacki kształt. I tu i tam - w Atawizmie i Wieczorze... - do uczuć atawistycznych zaliczane są miłość i współczucie oraz trak-

${ }^{13}$ Słowa „wozdusznik” („воздушник”) nie rejestrują współczesne rosyjskie słowniki objaśniające ani np. polskie słowniki rosyjsko-polskie. Jedynie w słowniku objaśniającym Dmitrija Uszakowa z 1935 roku znajdujemy ten wyraz w znaczeniu „специалист по воздушным сообщениям” poprzedzony kwalifikatorem „нов.”, со wskazuje, że pojawił się on w języku rosyjskim w czasach I wojny światowej i rewolucji, czyli od 1914 roku. Zob. А-Кюрины, Д.Н. Ушаков (red.), Толковый словарь русского языка, t. 1, ОГИЗ, Москва 1935, s. 339. Rzecz jasna, znaczenie słownikowe nie pokrywa się z tym, w jakim wozdusznik występuje w tekście Nikołaja Fiodorowa. Tutaj oznacza on raczej rodzaj środka transportu, który z platformy na ziemi przewoził pasażerów aż do stacji pod samą kopułą. Tego samego zdania jest Bugajewa. Zob. Л.Д. Бугаева, Tonoc и телос..., s. 74 .

${ }^{14}$ Н. Федоров, Вечер... в 2217 году..., s. 29. Osobisty numer identyfikacyjny Agłai - 4372221 - być może miał jednocześnie informować o liczbie mieszkańców Petersburga przekraczającej wtedy cztery miliony. 
towane w kategorii największych wrogów wyspiarskiej i petersburskiej społeczności, w której nie ma miejsca na przejawy indywidualizmu. Inni są odbierani w tekście z 1899 roku jako chorzy i tylko tacy decydują się na wielkie czyny: w finale Atawizmu współczująca „chora istota” podejmuje desperacki czyn i porywa pojazd międzyplanetarny, by razem z dwojgiem dzieci opuścić wyspę szczęśliwości. W Wieczorze... główna bohaterka w końcu opowiadania rzuca się pod wozdusznik, niczym tytułowa protagonistka powieści Lwa Tołstoja Anna Karenina (Анна Каренина, 1877) pod nadjeżdżający pociąg, i ginie na miejscu. Agłaja uwalnia się w ten radykalny sposób od problemu osobistego i petersburskiej kopuły jako symbolu totalnych ograniczeń.

Zdaniem Hellera i Niqueux Fiodorow wprowadza do literatury rosyjskiej tematy i chwyty typowe dla utworów antyutopijnych ${ }^{15}$. Jego Atawizm nawiązuje wyraźnie do dystopii When the Sleeper Wakes Herberta George’a Wellsa (1866-1946) przez powtórzenie tego samego klucza inicjującego polegającego na przebudzeniu się bohatera po 203-letnim śnie w odmiennej rzeczywistości Londynu. Zauważmy, że powieść Wellsa ukazała się w 1899 roku, a więc w tym samym, co publikacja Fiodorowa w moskiewskim czasopiśmie; zbieżność, przyznać trzeba, symptomatyczna. Drugim punktem odniesienia według francuskich badaczy jest antysocjalistyczna parodia Jerome’a K. Jerome’a (1859-1927) z 1891 roku The New Utopia, którą także ze względu na datę druku mógł znać petersburski dziennikarz. Skoro zatem Heller i Niqueux, a także autorzy przywołanych wcześniej antologii zawierających rosyjskie (radzieckie) teksty antyutopijne uważają Wieczór.. Fiodorowa za utwór należący do dystopii ${ }^{16}$, dziwi mnie, dlaczego Bugajewa zajęła

\footnotetext{
${ }^{15}$ Л. Геллер, М. Нике, Утопия в России..., s. 182. Zob. rozdział 5: Модернистские утопии і podrozdział: Светопредставления и идиллии.

${ }^{16} \mathrm{~Np}$. w serii „Utopia i Antyutopia XX Wieku” („Утопия и антиутопия XX века", Издательство Прогресс, Москва 1990) obok opowiadania Nikołaja Fiodorowa Wieczór w 2217 roku zamieszczono następujące teksty: Walerij Briusow, Республика Южного Креста, Aleksandr Bogdanow, Красная Звезда, Aleksandr Czajanow, Путешествие моего брата Алексея в страну крестьянской утопии, Jakow Okuniew, Грядущции мир, Jewgienij Zamiatin, $\mathrm{Mbl}$, Władimir Wojnowicz, Москва 2042.
} 
całkiem odmienne stanowisko. Uważa ona bowiem, że analizowane opowiadanie reprezentuje problematykę toposu i telosu, ale petersburskiej utopii, a nie antyutopii. Skupia się w swoim studium na konstrukcji semiotycznej przestrzeni Wieczoru..., w której realna geografia Petersburga miesza się z rzeczywistością magiczną, i podkreśla ich istotną bliskość, silne wewnętrzne powiązanie. Zdaniem rosyjskiej badaczki Fiodorow prowadzi dialog z utopią chrześcijańskiego socjalisty Edwarda Bellamy’ego (1850-1898), odzwierciedloną we śnie głównego bohatera jego utworu z 1888 roku Looking Backward, 2000-1887. Twierdzi ponadto, że wypowiedź stołecznego żurnalisty koresponduje z takimi utworami utopijnymi, jak chociażby Williama Morrisa News from Nowhere (1890), Ebenezera Howarda To-Morrow: A Peaceful Path to Real Reform (1898), Herberta G. Wellsa A Modern Utopia (1905), Nikołaja Szełonskiego В мире будущего (1892), Porfirija Infantjewa На другой планете (1901), Konstantina Mierieżkowskiego Paй земной, или Сон в зимнюю ночь. Сказка-утопия XVII века (1903) czy Aleksandra Bogdanowa Красная Звезда (1908). Ву nie być gołosłownym, zacytuję jedną z charakterystycznych opinii Bugajewej:

В русской утопии обсуждение проблем человеческой селекции также оказывается связанным с обсуждением моделей и путей развития общества, в первую очередь - социалистической. Иногда можно слышать мнения, что принцип борьбы за существование и другие идеи Мальтуса не созвучны русской ментальности. Однако именно идеи Мальтуса, Хаксли и Уэллса обыгрываются в небольшой повести петербургского журналиста Николая Д. Федорова „Вечер в 2217”, вышедшей [...] в СанктПетербурге в 1906 году и ставшей текстом-симптомом, в котором проявились характерные черты русской, более того - петербургской, утопии $^{17}$.

Wydaje mi się, że Bugajewa nie do końca jednak jest przekonana o wyłącznie utopijnym wymiarze Wieczoru... Fiodorowa jako osi konstrukcyjnej jego opowiadania, wyczuwa bowiem w analizowanym utworze nie rozkwit, ale schyłkowość atrakcyjności koncepcji utopijnych. Pisze przecież:

\footnotetext{
${ }^{17}$ Л.Д. Бугаева, Топос и телос..., s. 72 . Tu i dalej podkr. - G.O.
} 
Несмотря на отдельные параллели с построенным на идеях классического марксизма утопическим обществом в романе Э. Беллами, государство в утопии Федорова лишено характерного для утопии Беллами оптимизма и веры в прогресс. Надеждам рабочих, собравшихся в 1876 г. на демонстрацию перед Казанским собором, в утопии Федорова не суждено сбыться. Не ведет к светлому будущему и человеческая селекция: мужчины-избранники не являются высшей расой, подобной „самураям” Уэллса. В отсутствие „этической революции” и они, и рядовые Армии Труда были и остаются рабами. Прекрасная эпоха в российской действительности предстает в результате закатом утопической картины мира, временем, когда происходит смена утопической картины мира на дистопическую ${ }^{18}$.

W podstawowych definicjach antyutopii wskazuje się na jej przeciwieństwo w stosunku do utopii, a więc utwory o cechach dystopii dają negatywny obraz przyszłości, pokazują świat nieludzki, „biurokratycznie zorganizowany, w którym prawa jednostki są ograniczone przez totalitarne mechanizmy"19. Występowanie cech typowych dla antyutopii w analizowanym utworze Fiodorowa przesądza moim zdaniem o przynależności Wieczoru... do tego gatunku. Współcześnie dzieli się w literaturoznawstwie te teksty na przykład według czterech następujących kryteriów: 1. antyutopia apokaliptyczna, 2. antyutopia satyryczna, 3. antyutopia analityczna i 4. antyutopia rewolucyjna. Z pewnością Wieczór... Fiodorowa pasuje do pierwszego kryterium i reprezentuje tę wizję przyszłości, w której dochodzi do katastrofy-dehumanizacji, gdzie obserwujemy upadek starych tradycji rodzinnych na rzecz prokreacyjnej produkcji i gdzie totalitarny system sprawowania władzy nie daje szczęścia wszystkim obywatelom, chociaż takie jest jego główne przesłanie ideologiczne.

Według rosyjskiego literaturoznawcy, Borisa Łanina, można wskazać następujące cechy antyutopii: polemika z określonym projektem utopijnym, pseudokarnawalizm rzeczywistości, karnawałowy rytualizm, występowanie błazeńskiego obrzędu „zaślubin kró-

\footnotetext{
${ }^{18}$ Tamże, s. 75.

${ }^{19}$ M. Głowiński, T. Kostkiewiczowa, A. Okopień-Sławińska, J. Sławiński, Podręczny słownik terminów literackich, OPEN, Warszawa 2002, s. 24-25. Zob. jeszcze hasło „Antyutopia” w: G. Gazda, S. Tynecka-Makowska (red.), Słownik rodzajów i gatunków literackich, Universitas, Kraków 2006, s. 29-34.
} 
la", ekscentryczność protagonisty, rytualizm życia, alegoryczność. Łanin uważa, że oś konfliktu w dystopii opiera się na istotnych rozbieżnościach między jednostką i społeczeństwem i że antyutopia opowiada o znacznie bardziej realnych i łatwiejszych do domyślenia się rzeczach, aniżeli fantastyka naukowa. Wskazuje zarazem na zapożyczanie od fantastyki naukowej niezliczonych transformacji struktur czasowych. Podkreśla, że przestrzeń antyutopii jest ograniczona, a strach wypełnia całą atmosferę tego typu gatunku ${ }^{20}$.

Z kolei dzięki analizom wielu utworów antyutopijnych innej literaturoznawczyni rosyjskiej, Lidii Jurjewej, można podać następujące specyficzne cechy tego gatunku. Tak więc przestrzeń dystopii obejmuje państwo o systemie totalitarnym, terytorium tego państwa jest odgrodzone ogromną ścianą od innego świata, człowiek jest niewolnikiem zaprzęgniętym do udziału w absurdalnych czynnościach, przeszłość jest przez władzę odrzucona i skazana na zapomnienie, a główny bohater to najczęściej samotny buntownik skazany na konflikt $\mathrm{z}$ samym sobą i kolektywem, który myśli jak większośćc ${ }^{1}$. Ponadto w utworach antyutopijnych totalitaryzmowi przeciwstawia się miłość, a więc systemowi - emocje, a przyroda ze względu na swoje piękno kontrastuje z brzydotą społecznej codzienności. Świat nie jest tutaj absolutnie statyczny, lecz tylko potencjalny. Narracja często przybiera postać dziennika. Związki między przeszłością, teraźniejszością i przyszłością są osłabione ${ }^{22}$.

Trudno i raczej bezpodstawnie byłoby żądać, aby Wieczór... Fiodorowa realizował wszystkie lub przynajmniej większość kryteriów, o których pisali Łanin i Jurjewa, zwłaszcza że mamy tutaj do czynienia zaledwie z niewielkim objętościowo opowiadaniem.

${ }^{20}$ Б.А. Ланин, Анатомия литературной антиутопии, „Общественные науки и современность” 1993, nr 5, s. 154-163.

21 Л.М. Юрьева, Русская антиутопия в контексте мировой литературь, ИМЛИ РАН, Москва 2005, s. 73-76.

${ }^{22}$ Warto przywołać w tym miejscu także wartościowe opracowanie polskiej badaczki, która podjęła problematykę antyutopii w literaturze rosyjskiej, ilustrując swoje spostrzeżenia tekstami Andrieja Płatonowa, Andrieja Siniawskiego, Aleksandra Zinowjewa, Władimira Wojnowicza i Jewgienija Zamiatina. Zob. K. Duda, Antyutopia w literaturze rosyjskiej XX wieku, Wydawnictwo Uniwersytetu Jagiellońskiego, Kraków 1995.

RSL.2021.31.06 s. 13 z 19 
Niemniej są one obecne w tym tekście, co dodatkowo przemawia za traktowaniem go jako dystopii. Wieczór... składa się kompozycyjnie z 12 części, narracyjnie dłuższych i krótszych, które nie stanowią na ogół zamkniętych odcinków wypowiedzi, ponieważ autor swobodnie przemieszcza się z końca jednego fragmentu do następnego, a sam podział graficzny za pomocą wielkich cyfr rzymskich wydaje mi się zbędny. Innymi słowy, w mojej ocenie analizowany utwór nic nie zyskuje na podziale strukturalnym zaproponowanym przez autora i nic zapewne narracyjnie by nie stracił, gdyby danego podziału nie było. Jest to oczywiście ocena subiektywna, nie da się bowiem wykluczyć założenia, że taki podział tekstu stanowi element autorskiej metody.

Akcja Wieczoru... toczy się w XXIII wieku. Rozpoczyna się o godzinie 16 na rogu dwóch prospektów - Newskiego i Litiejnego - i w tym samym miejscu się kończy kilkanaście dni później; kompozycyjna klamra. Mieszkańcy Petersburga jako kolektyw nie dostrzegają ceny, jaką zapłacili i wciąż płacą za „egzystencjalny luksus” życia pod kopułą miasta. Nie rozumieją, że są jedynie bezdusznymi śrubeczkami w ogromnej machinie totalitarnego państwa, dbającego wyłącznie o wydajność Armii Pracy i podtrzymanie permanentnego procesu reprodukcyjnego w celu zapewnienia nowych rąk do codziennej pracy. Tęskniący za miłością i rodziną starego typu, pragnący życia na modłę sprzed nawet setek lat, jak Agłaja czy Paweł, należą do rażącej społecznie mniejszości i ich marzeniom nie jest pisane się spełnić.

Fiodorow prowadzi dialog, bo raczej nie polemizuje, nie tylko z Lwem Tołstojem, Herbertem George'em Wellsem i Jerome'em K. Jerome'em, ale także, jak sądzę, z Fiodorem Dostojewskim i jego myślą o Wielkim Inkwizytorze, przedstawioną w Braciach Karamazow. Wybiera dla niego jednak inne pole aktywności: niwę seksualnej ekspansji. Uczony Karpow z Wieczoru... to świeżo upieczony doktor nauk historycznych, przystojny i atrakcyjny fizycznie samiec, u którego zjawiają się „dobrowolnie” na zapisy dziewczęta i kobiety w wieku 25-26 lat, a więc - w utworze - na granicy prokreacyjnej przydatności, niebędące w związkach i niemające dzieci. Spędza on ze „starymi pannami” intymne chwile tylko po to, by unasien- 
nić niewiasty, skutek zaś nie jest istotny. Spółkowanie pod presją społeczną, w obawie, by nie zostać okrzykniętą jako element wrogi i przez to zbędny w społeczeństwie, urasta tutaj do rangi wielkiego wyczynu, a sam Karpow - do groteskowej roli Wielkiego Inseminatora. Petersburski dziennikarz tak pisze o potencjalnych matkach z konieczności, dbając o szczegóły w przedstawianiu ich wyglądu i zachowania się w pokoju przyjęć:

В комнате, светлой, но заставленной цветами, сидело уже больше двадцати женщин и девушек, и каждую минуту прибывали все новые. Некоторые, видимо, были смущены и сидели опустив глаза и сложив руки; другие разговаривали вполголоса. Комната наполнялась, и казалось, что в ней не хватит места, чтобы принять всех желающих записаться у восходящего светила. А они все шли и шли, и каждую минуту подъемная машина выпускала их на площадку по одной, по две, по три.

Около половины третьего вышел в мягком домашнем костюме и в мягких туфлях Карпов. Женщины уже избаловали его, но сегодняшним наплывом он был, повидимому ${ }^{23}$, все-таки смущен и остановился в замешательстве.

Было больше пятидесяти кандидаток. Остановившись посреди комнаты, Карпов сделал общий поклон и обвел глазами лица и фигуры. Совсем некрасивых не было. Как всегда, у каждой на плече был пришит ее рабочий номер. И, вынув маленькую с золотым обрезом книжечку и крохотный карандаш, Карпов отметил несколько номеров, еще раз обводя взглядом всех кандидаток, и, сделав снова общий поклон, скрылся в ту же дверь, через которую вошел ${ }^{24}$.

Wizyta 26-letniej Agłai u Karpowa i spędzona z nim noc w celach prokreacyjnych stała się dramatycznym momentem zwrotnym w psychice młodej kobiety. Poczucie obrzydzenia do samej siebie zmusza dziewczynę do odrzucenia oświadczyn Pawła Witinskiego, mężczyzny równie "zwariowanego" na punkcie życia w rodzinie starego typu. Pod wpływem świeżych emocji Agłaja poddaje się bardzo szybko, rezygnuje $\mathrm{z}$ realnej możliwości założenia rodziny, o jakiej zawsze marzyła. Tak samo zresztą szybko godzi się z odmową dziewczyny Paweł, którego przecież z wzajemnością skrycie

\footnotetext{
${ }^{23}$ Łączny zapis przysłówka jest zgodny z oryginałem w odróżnieniu od pisowni współczesnej (по-видимому). Н. Федоров, Вечер... в 2217 году..., s. 11.

${ }^{24}$ Н. Федоров, Вечер... в 2217 году..., s. 10-11.
}

RSL.2021.31.06 s. 15 z 19 
kochała. To tragiczne rozwiązanie zaproponowane przez Fiodorowa uważam za słabo psychologicznie umotywowane. Pozwoliło ono jednak urwać narrację jakby w pół słowa i zmusić czytelnika do wywołania w nim określonych emocji w skali od obojętności do hiperempatii.

Zarówno słowo „protest”, jak i przestarzałe obecnie "protestacja” mają źródłosłów łaciński. Pierwsze pochodzi od wyrazu protestor w znaczeniu 'oświadczam', drugie wywodzi się od protestatio 'stwierdzenie'. W obydwu konotacjach zawiera się jednak ten sam wyraźny sprzeciw osoby, która zdecydowanie występuje przeciw czemuś, co uznała za niesłuszne. Swoją postawę opozycyjną pisarz może zademonstrować przez odwołanie się na przykład do jednego z dwóch gatunków, niejako predestynowanych do przeciwstawienia się temu, z czym się nie zgadza; mam na myśli przede wszystkim utopię i antyutopię. W obydwu rozwiązaniach narracyjnych występuje diagnoza rzeczywistości, z którą twórca ostro polemizuje, i te obydwa rozwiązania strukturalne są powołane do wyrażenia protestu, do przeprowadzenia swego rodzaju PRO-testu na kondycje świata. O ile jednak w utopii autor zarysowuje idylliczne obrazy, $\mathrm{w}$ jego ocenie pożądane, rajskie i harmoniczne, z przekonaniem zachęca do przybliżenia się do nich, o tyle w antyutopii przestrzega przed poważnymi konsekwencjami tego, czego jest świadkiem: przed chaosem i jego katastroficznymi - pod różnymi względami - konsekwencjami, odradza podążanie w niebezpiecznym kierunku. Wizje pisarza-antyutopisty, nawet bardzo odległe w czasie fizycznym, sięgającym setek lat do przodu, zawierają niezwykle czytelne przesłanie: zróbmy coś, by nie stało się tak, jak o tym piszę.

Wieczór... w 2217 roku Nikołaja D. Fiodorowa jest bez wątpienia antyutopijnym, a nie utopijnym literackim tekstem-protestem przeciwko presji, jaką wywiera na jednostkę system totalitarnego państwa, buntem przeciwko permanentnemu podglądaniu intymnej sfery życia człowieka przez osoby identyczne $\mathrm{z}$,tysiackimi", reprezentowanymi $\mathrm{w}$ opowiadaniu przez niesympatyczną i tępą emocjonalnie strażniczkę porządku publicznego Krag, ponoszącą odpowiedzialność za przedwczesną śmierć Agłai z powodu natrętnego przymuszania jej do seksu z Karpowem. Utwór Fiodorowa 
przekonuje, że żadne koncerty aromatyczne, którymi syci się zmysły mieszkańców Petersburga, nie są w stanie wyeliminować poważnych wątpliwości o naturze człowieka i wartości utrwalonych w tradycji narodu oraz państwa. Petersburski dziennikarz sprzeciwia się codziennej szarzyźnie egzystencji numerów, przeciwstawiając jej piękno i niezwykłość miejskiej przyrody. Akcja opowiadania toczy się przecież wiosną, gdy tradycyjnie w powietrzu unosi się najwięcej czarownych aromatów. Fiodorow zdecydowanie nie godzi się na unifikację potrzeb oraz oczekiwań człowieka, gdy wprowadza do utworu bezwolną i kompromisową postać Luby, koleżanki Agłai z Armii Pracy. Pogląd Luby na rzeczywistość jest opinią większości:

Столетиями, тысячелетиями стонало человечество, мучилось, корчилось в крови и слезах... Наконец его муки были разрешены, оно дошло до решения вековых вопросов; нет больше несчастных, обездоленных, забытых; все имеют доступ к свету, теплу, все сыты, все могут учиться... ${ }^{25}$

Fiodorow proroczo przewidział to, co wydarzy się po rewolucji bolszewickiej 1917 roku. W zniewolonym przez sowieckie władze państwie obywatele staną się wkrótce niewolnikami-rabami, o których mówił Paweł, a pozorny tylko głos większości będzie oficjalną przykrywką dla Kremla w stosowaniu polityki drastycznych represji. „Jest jeden straszny pan — konkludował młody mężczyzna — to tłum, ta wasza straszna większość”. Autor Wieczoru... odważnie powiedział ustami Pawła, że większość jest przeklęta, bo bezmyślna, i ciąży w sercu jak kamień, który powstrzymuje wszelki swobodny ruch. Pisarz zaprotestował przeciwko temu, co mogło nadejść, i co niestety nadeszło znacznie wcześniej, niż zakładał.

\section{REFERENCES}

Bugayeva, Lyubov’ D. “Topos i telos peterburgskoy utopii: Nikolay Fedorov.” Mezhdunarodnyy zhurnal issledovaniy kul'tury, no. 4 (9), 2012: 71-75 [Бугаева, Любовь Д. “Топос и телос петербургской утопии: Николай Федоров.” Международный журнал исследований культурь, № 4 (9), 2012: 71-75].

\footnotetext{
${ }^{25}$ Tamże, s. 20.
} 
Ciencia ficción rusa y soviética. Vol. 1. Ed. Womack, James. Madrid: Ediciones Nevsky, 2016.

Duda, Katarzyna. Antyutopia w literaturze rosyjskiej XX wieku. Kraków: Wydawnictwo Uniwersytetu Jagiellońskiego, 1995.

Fedorov, Nikolay F. Filosofiya obshchego dela. Vol. 1. Vernyy: Tip. Semirechen. Oblastnogo pravleniya, 1906. Vol. 2. Moskva: Pechatnya A. Snegirevoy, 1913 [Федоров, Николай Ф. Философия общего дела. Т. 1. Верный: Тип. Семиречен. Областного правления, 1906. Т. 2. Москва: Печатня А. Снегиревой, 1913].

Fedorov, Nikolay F. Sobraniye sochineniy: $v$ 4-kh tt. Ed. Blauberg, Irina I. Moskva: Progress-Traditsiya, Evidentis, 1995-2004 [Федоров, Николай Ф., Собрание сочинений: в 4-х mm. Сост. Блауберг, Ирина И. Москва: Прогресс-Традиция, Evidentis, 1995-2004].

Fedorov, Nikolay. “Vecher v 2217 godu.” DARKER, no. 12'16 (69), 2016 [Николай, Федоров. “Вечер в 2217 году.” DARKER, № 12’16 (69), 2016)].

Fedorov, Nikolay. "Vecher v 2217 godu." Fantastika Serebryanogo veka. Vol. 7: Bomba professora Shturmvel'ta. Ed. Fomenko, Mikhail, Sherman, Adam. 39-56. Moskva: Salamandra P.V.V., 2018. http://az.lib.ru/f/fedorow_n_d/ text_1906_vecher.shtml. Accessed 6 January 2021 [Николай, Федоров. “Вечер в 2217 году.” Фантастика Серебряного века. Т. 7: Бомба профессора Штурмвельта. Сост. Фоменко, Михаил, Шерман, Адам. 39-56. Москва: Salamandra P.V.V., 2018. http://az.lib.ru/f/fedorow_n_d/text_1906_vecher. shtml. Дата обращения: 6 января 2021].

Fedorov, Nikolay. Vecher... v 2217 godu s poslesloviyem. S.[ankt]-Peterburg: Tipo-Litogr[afiya]. "Gerol'd," 1906 [Федоров, Николай. Вечер... в 2217 году с послесловием. С.[анкт]-Петербург: Типо-Литогр.[афия] “Герольд”, 1906].

Geller, Leonid, Nike, Mishel'. Utopiya v Rossii. Transl. from French Bulatovskiy, Igor' V. Sankt-Peterburg: Giperion, 2003 [Геллер, Леонид, Нике, Мишель. Утопия в России. Пер. с фр. Булатовский, Игорь В. Санкт-Петербург: Гиперион, 2003].

Głowiński, Michał, Kostkiewiczowa, Teresa, et al. Podręczny słownik terminów literackich. Warszawa: OPEN, 2002.

Heller, Leonid, Niqueux, Michel. Histoire de l'utopie en Russie. Paris: Presses Universitaires de France, 1995.

Księga Rodzaju. Przeł. i oprac. Piela, Marek. Kraków: Wydawnictwo Księgarnia Akademicka, 2020.

Lanin, Boris A. "Anatomiya literaturnoy antiutopii." Obshchestvennyye nauki i sovremennost', no. 5, 1993: 154-163 [Ланин, Борис А. “Анатомия литературной антиутопии.” Общественные науки и современность, № 5, 1993: 154-163].

Łużny, Ryszard. "Myśl filozoficzna Mikołaja Fiodorowa w kręgu pisarzy rosyjskich XIX i XX wieku.” Przegląd Humanistyczny, no. 1-2, 1982: 99-116.

Madej-Cetnarowska, Monika. Myśl Nikołaja Fiodorowa w literaturze dziewiętnastego i dwudziestego wieku. Nowy Sącz: Wydawnictwo Naukowe Państwowej Wyższej Szkoły Zawodowej w Nowym Sączu, 2013. 
Pietrzycka-Bohosiewicz, Krystyna. "Przerzucić most nad rzeką czasu...' Nikołaj Fiodorow i pisarze rosyjsсу.” Строитель чудотворный [Stroitel' chudotvornyy]. Szkice o literaturze rosyjskiej dedykowane Jadwidze Szymak-Reiferowej i Władysławowi Piotrowskiemu. Ed. Waszkielewicz, Halina, Świeży, Janusz. 105-111. Kraków: Tertium, 2001.

Polden', XIX vek. Ed. Gulyj, Aleksandr, Isaev, Vladislav. Moskva: Korporatsiya “Sombra," 2005 [Полдень, ХІХ век. Сост. Гулый, Александр, Исаев, Владислав. Москва: Корпорация “Сомбра," 2005].

Red Star Tales: A Century of Russian and Soviet Science Fiction. Ed. Howell, Yvonne. Montpelier (VT): Russian Life Books, 2015.

Russkaya fantastika kontsa XIX - nachala XX veka. Vol. 10: Vecher v 2217 godu. Ed. Medvedev, Yuriy. Moskva: Russkaya kniga, 1998 [Русская фантастика конца XIX - начала XX века. Т. 10: Вечер в 2217 году. Сост. Медведев, Юрий. Москва: Русская книга, 1998].

Russkaya literaturnaya utopiya. Ed. Shestakov, Vyachelav. Moskva: Izdatel'stvo Moskovskogo universiteta, 1986 [Русская литературная утопия. Ред. Шестаков, Вячеслав. Москва: Издательство Московского университета, 1986].

Słownik rodzajów i gatunków literackich. Ed. Gazda, Grzegorz, Tynecka-Makowska, Słowinia. Kraków: Universitas, 2006.

Tolkovyy slovar' russkogo yazyka. Vol. 1. A-Kyuriny. Ed. Ushakov, Dmitriy N. Moskva: OGIZ, 1935 [Толковый словарь русского языка. Т. 1. А-Кюрины. Ред. Ушаков, Дмитрий Н. Москва: ОГИЗ, 1935].

Yur'yeva, Lidiya M. Russkaya antiutopiya v kontekste mirovoy literatury. Moskva: IMLI RAN, 2005 [Юрьева, Лидия М. Русская антиутопия в контексте мировой литературы. Москва: ИМЛИ РАН, 2005].

Vecher v 2217 godu. Ed. Shestakov, Vyachelav. Moskva: Progress, 1990 [Вечер в 2217 году. Сост. Шестаков, Вячеслав. Москва: Прогресс, 1990]. 